\title{
Estimation of Organic Content and Carbon Uptake in Sonneratia alba (Smith) Mangroves in Aquaculture Areas: a Case Study in the Marine and Brackish Water Cultivation Area of Probolinggo City, Indonesia
}

\author{
Sulastri Arsad ${ }^{1,4,5}$, Monica Like Ernize ${ }^{2}$, Suryanti $^{3}$, \\ Yenny Risjani', Muhammad Musa ${ }^{1,4 *}$ \\ ${ }^{1}$ Department of Aquatic Resources Management, Faculty of Fisheries and Marine Science, \\ Universitas Brawijaya, Jl. Veteran Malang 65145, Indonesia \\ ${ }^{2}$ Undergraduate Student at Faculty of Fisheries and Marine Science, Universitas Brawijaya, \\ Jl. Veteran Malang 65145, Indonesia \\ ${ }^{3}$ Department of Aquatic Resources, Faculty of Fisheries and Marine Science, Universitas Diponegoro, \\ Jl. Prof. Soedarto, SH Tembalang, Semarang 50275, Indonesia \\ ${ }^{4}$ AquaRES Research Group, Faculty of Fisheries and Marine Science, Universitas Brawijaya. \\ Jl. Veteran Malang 65145, Indonesia \\ ${ }^{5}$ MicroBase Research Group, Postgraduate Department, Universitas Brawijaya, \\ Jl. Veteran Malang 65145, Indonesia
}

Received: 11 April 2021

Accepted: 27 July 2021

\begin{abstract}
This study aims to analyze the value of organic carbon content and $\mathrm{CO}_{2}$ uptake in the leaves, roots and sediments of Sonneratia alba mangroves. The research location was in the area of Marine and Brackish Water Cultivation area of Probolinggo City. The research method used was a survey method and the sampling was done by a non-destructive method. The results show that the highest average biomass value in the leaves, roots, and sediments respectively is in the ratio of 7: 8: 9. The highest average carbon content value in the leaves, roots, and sediments respectively is the ratio of 14: 17: 1 . The conclusion in this study is that the carbon content in each component of the leaves, roots and sediments is 20.72 g. $\mathrm{m}^{-2}, 24.76$ g. $\mathrm{m}^{-2}, 1.49$ g. $\mathrm{m}^{-2}$, respectively and the carbon dioxide uptake in the leaves, roots, and sediments is $90.80 \mathrm{~g} . \mathrm{m}^{-2}, 75.98 \mathrm{~g} . \mathrm{m}^{-2}, 5.46 \mathrm{~g} . \mathrm{m}^{-2}$ with a ratio of 14: 17: 1 .
\end{abstract}

Keywords: carbon dioxide, coastal habitat, ecology, mangrove

*e-mail: musa_fpi@ub.ac.id 


\section{Introduction}

Natural forests are a source of carbon storage because they have a high diversity of tree vegetation [1]. Therefore, many efforts have been done for the environmental development so that the amount of carbon dioxide in the air can be controlled by increasing the amount of $\mathrm{CO}_{2}$ uptake by plants as much as possible in order to release carbon dioxide emissions into the air as low as possible [2]. Mangroves are natural resources on the coast that have functions as protection, maintenance and nature conservation [3]. Mangrove ecosystems have a role in absorbing carbon dioxide $\left(\mathrm{CO}_{2}\right)$ from the air [4]. However, if the function of the mangrove ecosystem is converted into agricultural land, aquaculture, and industrial activities, the amount of carbon stored will decrease [5]. For this reason, there is a need for the monitoring of the mangrove ecosystem in absorbing carbon and for the evaluation of the mangrove ecosystem, especially in degraded marine ecosystems [6]. The coastal area of Probolinggo has a wide variety of mangrove species. One of them is the mangrove Sonneratia alba.

Sonneratia alba belong to mangroves that can grow in tropical and subtropical coastal areas and have distinctive morphological characteristics so that they can survive in environments that have very high salinity [7]. This study aims to analyze the value of organic carbon content and $\mathrm{CO}_{2}$ uptake in the leaves, roots and sediments of $S$. alba.

\section{Materials and Methods}

The research was carried out in December 2019 - January 2020 in the Marine and Brackish Water Cultivation area of Probolinggo City by using survey method. Sampling was carried out 3 times at 3 sampling points (Site 1, 744'27.3” S dan 113 ${ }^{\circ} 13^{\prime} 59.7^{\prime \prime} \mathrm{E}$; site 2, $7^{\circ} 44^{\prime} 28.5^{\prime \prime} \mathrm{S}$ dan $113^{\circ} 13^{\prime} 58.0^{\prime \prime} \mathrm{E}$; dan site 3, 744'27.5" $\mathrm{S}$ dan $\left.113^{\circ} 13^{\prime} 56.1^{\prime \prime} \mathrm{E}\right)$. The location of the research area (Fig. 1) on the southern side is a river that directly flows into the sea and on the northern side is the residents' ponds. Meanwhile, on the eastern side is the open sea and on the western side are the Probolinggo-Situbondo Pantura highway and settlements.

The types of mangrove plants in the research area consist of Avicennia sp., Rhizopora sp., Bruguiera sp., and Sonneratia alba. The sampling of tree sizes was done randomly with the assumption that they were the representatives of the entire vegetation. The leaves, roots and sediments components were taken from each of the three sites. In addition, the environmental parameter measurements were carried out at each site. Sampling in this study used non-destructive sampling method.

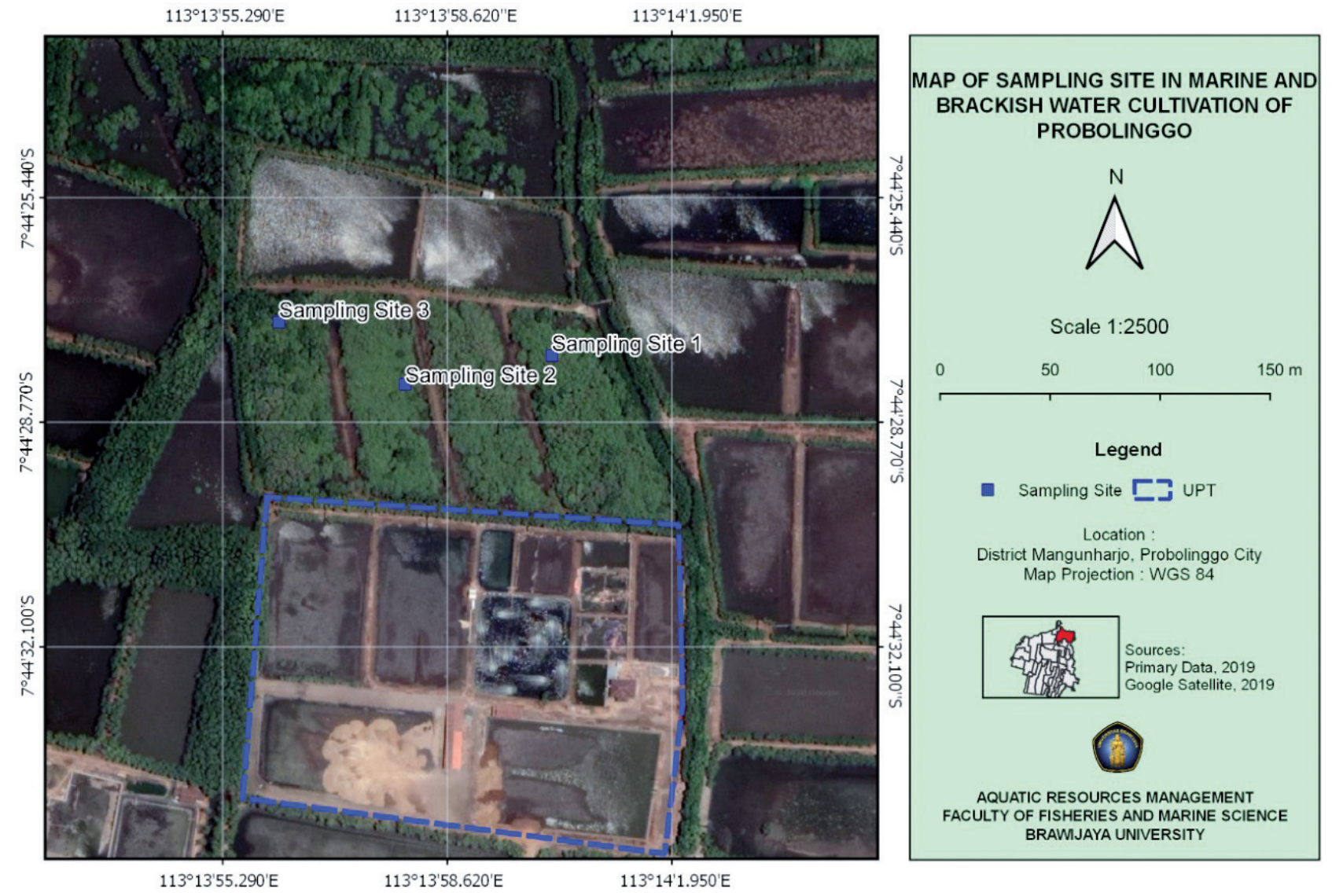

Fig. 1. Mangrove research location. 


\section{Sample Analysis}

To determine the biomass, samples were analysed for dry weight of biomass using the formula [8]. Therefore, the C-organic analysis using leaf, root and sediments samples used the Walkey and Black method. Moreover, according to [9], the calculation of the amount of organic carbon produced is based on the amount of biomass. Determination of $\mathrm{CO}_{2}$ absorption was calculated by using the formula by [10].

\section{Water and Soil Quality Parameters}

Water quality parameters measured were salinity (\%o, Refractometer), while soil quality parameters measured were temperature $\left({ }^{\circ} \mathrm{C}\right.$; soil tester AMT300), $\mathrm{pH}$ (soil tester AMT-300), nitrate (mg. L ${ }^{-1}$; [11]), and phosphates (mg. $\mathrm{L}^{-1}$; [12]).

\section{Statistical Analysis}

Statistical data analysis used one-way ANOVA test analysis with SPSS 18.0 software. The tests carried out included the normality test, the Levene's test of the homogeneity, and the Post Hoc test (LSD test and Games-Howell test).

\section{Results and Discussion}

\section{Biomass Value}

The coefficient of variance (CV) of leaf biomass is $6.03 \%$, root biomass is $9.01 \%$, and sediments biomass is $7.12 \%$. [13] state that the benchmark (critical limit) for $\mathrm{CV}$ based on a large number of field experiments conducted at different situations or times is $33 \%$, meaning that the $\mathrm{CV}$ value $<33 \%$ is uniform (not significantly different) and the $\mathrm{CV}$ value $>33 \%$ varies (significantly different). Hence, the results do not show a significant difference. The biomass for each component (leaves, roots, sediments) of Sonneratia alba mangrove can be seen in Fig. 2.

The biomass value that has been obtained can indicate how much carbon content is available or stored in a stand. This is because almost $50 \%$ of the biomass of a plant is composed of the element carbon. Therefore, the greater the value of the biomass, the greater the stored carbon content. If a forest is converted into agricultural land, plantations, and industrial areas, the amount of carbon stored will decrease and even disappear. Consequently, the carbon is released or carbon emissions occur which, if it occurs continuously, will lead to an increase in the amount of $\mathrm{CO}_{2}$ in the air and cause uncontrolled global warming [14].

\section{Organic Carbon Content}

The Coefficient of Variance (CV) value of carbon in the leaves, roots, and sediments are $16.72 \%, 12.98 \%$, and $27.91 \%$, consecutively. The results of the study on the carbon content of each component show no significant difference. Regarding the organic carbon content of Sonneratia alba from the three sites, the average value of the organic carbon content in the leaves, roots, and sediments are $20.72 \mathrm{~g} . \mathrm{m}^{-2}, 24.76 \mathrm{~g} . \mathrm{m}^{-2}$, and 1.49 g. $\mathrm{m}^{-2}$, respectively. Moreover, nutrients affect the value of biomass and thus affect the organic matter content (Table 1).

The comparison of the average value of organic carbon content in the leaves: roots: sediments obtain a ratio of 14: 17: 1 . The results of this research show that the carbon content of $S$. alba is directly proportional to the value of leaf and root biomass, but it is not applied to the sediments. The higher the biomass of the leaves and roots, the higher the organic carbon content. $45-50 \%$ of plant dry matter consists of carbon content [15]. This statement is reinforced by [16], stating that plant bodies, both living and dead bodies that fall to the ground, are called biomass. Biomass is a storage place for carbon and is called a carbon sink. One of the important carbon depletions is forests. Organic carbon

\section{Leaves [ Roots $\square$ Sediments}

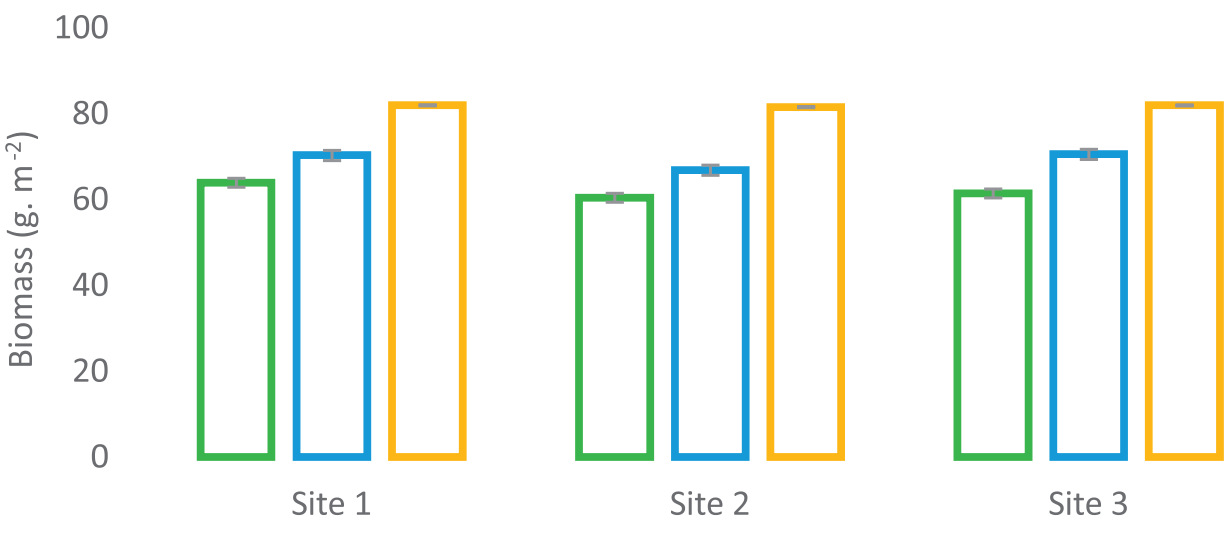

Fig. 2. Value of mangrove biomass. 
Table 1. Carbon content and the value of carbon uptake of mangroves on leaves, roots and sediments.

\begin{tabular}{|c|c|c|c|c|c|c|}
\hline \multirow{2}{*}{ Mangroves } & \multicolumn{3}{|c|}{ Carbon content $\left(\mathrm{g} . \mathrm{m}^{-2}\right)$} & \multicolumn{3}{c|}{ The value of carbon uptake $\left(\mathrm{g} . \mathrm{m}^{-2}\right)$} \\
\cline { 2 - 7 } & Site 1 & Site 2 & Site 3 & Site 1 & Site 2 & Site 3 \\
\hline Leaves & 21.32 & 19.85 & 21.00 & 78.18 & 72.77 & 77.01 \\
\hline Roots & 22.99 & 25.20 & 26.10 & 84.31 & 92.40 & 95.68 \\
\hline Sediment & 1.38 & 1.17 & 1.92 & 5.04 & 4.29 & 7.04 \\
\hline
\end{tabular}

levels also depend on the age and size of the plant itself. [17] state that carbon stocks increase depending on the size of the biomass. Sediments that have high biomass but low carbon content occur because the constituent components of sediments biomass are not organic carbon [17]. According to [18], the category of respiratory root type in $S$. alba can photosynthesize, absorb water and have many gaps for air entry, so it can absorb more carbon. The older the mangrove age, the wider the tree canopy, so that it can produce more biomass through the process of photosynthesis [19].

\section{$\mathrm{CO}_{2}$ Absorption}

Sonneratia alba mangroves have the ability to absorb $\mathrm{CO}_{2}$ through photosynthesis. It shows the ability of $S$. alba to absorb $\mathrm{CO}_{2}$ from the air which is then stored in the form of organic carbon. The CV value of carbon uptake in the leaves, roots, and sediments are $16.72 \%, 12.98 \%$ and $27.91 \%$, sequentially. The results of the calculation of the average carbon dioxide uptake of $S$. alba show that the carbon uptake in the leaves, roots, and sediments are $75.99 \mathrm{~g} . \mathrm{m}^{-2}, 90.80 \mathrm{~g} . \mathrm{m}^{-2}$, and 5.46 g. $\mathrm{m}^{-2}$, serially. Moreover, the comparison values of the mean carbon uptake of $\mathrm{CO}_{2}$ in leaves: roots: sediments obtain the results of the ratio of 14: 17: 1 . The Games-Howell test showed that the carbon dioxide uptake of $S$. alba in the sediment being significantly different from the leaf component and the sediment component being significantly different from the root component (Table 1).

The result of the absorption value of carbon dioxide absorbed is influenced by the content of organic carbon; the higher the organic carbon, the higher the carbon dioxide storage. Therefore, it can be concluded that there is a relationship between organic carbon and carbon dioxide storage, so if there is an increase and decrease of organic, there will also be an increase and decrease in carbon dioxide storage [20].

The large amount of water content in the leaves occurs because each leaf has a cell cavity that can be filled with water and mineral nutrients. Stomate in a large number found on the leaves cause water from the environment to be absorbed in large amount, compared to the lenticels found on the stems that can only absorb a small amount of water. The stomate found on the leaves also function to absorb carbon dioxide $\left(\mathrm{CO}_{2}\right)$ from the air and to release oxygen $\left(\mathrm{O}_{2}\right)$ which is then inhaled by all living things, especially humans. The increase in carbon uptake in mangrove vegetation is closely related to the size of a vegetation as the increase in the diameter and height of the tree will make the increase in the potential for carbon uptake. Trees absorb carbon dioxide from the air through photosynthesis, convert it into organic carbon (carbohydrates), and then store it in the form of biomass on stems, leaves, roots, branches, and twigs [21].

\section{Water and Soil Quality Parameters}

The results of measurements of water and soil quality parameters include water salinity, soil temperature, soil $\mathrm{pH}$, nitrate and phosphate. Salinity obtained was 19-31\%o. Salinity directly affects the growth rates and zoning of mangroves. This is related to the frequency of inundation, so that the high salinity value as a result of the measurement may be caused by the fact that when the water sample is taken, the water conditions are very receding. According to [22], Sonneratia species are generally found to live in areas with salinity close to the salinity of seawater. Some species can also live or grow at high salinity such as Rhizopora mucronata and Rhizopora stylosa which can grow at a salinity of 55\%. In general, the tolerance limit for mangrove growth ranges from $10-30 \%$.

The results of the soil temperature measurement range from $25-32^{\circ} \mathrm{C}$, [23] stated that mangroves can thrive in tropical areas in a temperature range of more than $20^{\circ} \mathrm{C}$. The environmental parameters measured at the location of this research are known to be parameters that support the optimum growth of mangrove vegetation. Furthermore, $\mathrm{pH}$ value in all sites show a range of values at 5-6.5, which is belong to acidic $\mathrm{pH}$ range due to the pyrite content in the sediments. The $\mathrm{pH}$ optimum for mangrove growth is 6.6-7.3 [24]. The $\mathrm{pH}$ range in this study is lower than the $\mathrm{pH}$ of seawater, which is 8-9, which can result in the formation of $\mathrm{H}_{2} \mathrm{~S}$ in water. The low $\mathrm{pH}$ value of the waters can be caused by the process of the decomposition of the organic matter by anaerobic bacteria, which produces organic acids. In addition, $\mathrm{H}_{2} \mathrm{~S}$ toxicity increases with the decreasing $\mathrm{pH}$ level because at $\mathrm{pH} 5$ sulphur is in the form of $\mathrm{H}_{2} \mathrm{~S}$ [25]. According [26], in the development of coastal swamps in intertidal zones covered by mangrove vegetation as an aquaculture, the soil contains pyrite (minerals with cubic crystal structure from iron sulphide compounds). 
After the completion of construction and drying, the soil at the bottom of the pond has a high level of acidity ( $\mathrm{pH} 2.5-5)$, and the acidity will increase after the pyrite is oxidized [27]. Acid sulphate soil is soil or sediments containing pyrite $\left(\mathrm{FeS}_{2}\right)$ in dry conditions which can be oxidized to dissolve $\mathrm{SO}_{4}$ and $\mathrm{Fe}$ and produce high acidity conditions or a decrease in soil $\mathrm{pH}$.

The results of the nitrate measurement results obtain a value range of $1.78-2.96 \mathrm{mg}$. $\mathrm{L}^{-1}$, classified as high value [28]. It indicates that the mangrove habitat is very fertile. In addition, nitrates can be used as a benchmark in determining the level of fertility in waters [29]; [30]. Then, the phosphate measurement is $2.35-7.65 \mathrm{mg}$. $\mathrm{L}^{-1}$. The high phosphate content in the mangrove sediments is caused by the entry of domestic, agricultural and fishery waste containing phosphate, previously used for aquaculture activities [31]; [32]. Organic matter, nitrates and phosphates contained in the sediments are nutrients that mangroves need for fertility. Sedimentation that occurs in mangrove areas is different from the sedimentation in other depositional environments [33]; [34]. Sources of sediments in mangrove areas come from land and sea (allocthonous) and from the mangroves themselves (autochtonous) in the form of piles of fallen leaves, twigs and dead organisms that are deposited in the mangrove area, containing a lot of organic and minerals ( $\mathrm{N}, \mathrm{P}, \mathrm{K}, \mathrm{Fe}$ and $\mathrm{Mg}$ ) [35]. A decrease in the quality of the mangrove environment will affect the distribution of nitrate and phosphate content in the sediments, which will affect the fertility of the mangroves [36].

\section{Conclusions}

In this present study, the highest average biomass value in the leaves, roots, and sediments respectively is in the ratio of 7: 8: 9. The highest average carbon content value in the leaves, roots, and sediments respectively is the ratio of 14: 17: 1 . The conclusion in this study is that the carbon content in each component of the leaves, roots and sediments is 20.72 g. m-2, 24.76 g. m-2, 1.49 g. m $\mathrm{m}^{-2}$, respectively and the carbon dioxide uptake in the leaves, roots, and sediments is $90.80 \mathrm{~g} . \mathrm{m}^{-2}, 75.98 \mathrm{~g} . \mathrm{m}^{-2}, 5.46 \mathrm{~g}$. $\mathrm{m}^{-2}$ with a ratio of $14: 17: 1$.

\section{Acknowledgments}

The authors would like to give great gratitude to the Brackish and Marine Field Lab, Faculty of Fisheries and Marine Sciences, Universitas Brawijaya for the research facilities provided.

\section{Conflict of Interest}

The authors declare no conflict of interest.

\section{References}

1. POORTER L., VAN DER SANDE M.T., THOMPSON ARET E.J.M.M., et al. Diversity enhances carbon storage in tropical forests. Global Ecology and Biogeography, 24 (11), 1314-1328. DOI: 10.1111/geb.12364, 2015.

2. SAPUTRA D.K., SEMEDI B., DARMAWAN A., MUTHFI O.M., HANDAYANI M., ARSAD S. Habitat management based on mangrove sensitivity assesment in Tulungagung coastal area. Ecsofim journal, 07 (02), 258, http://dx.doi.org/10.21776/ub.ecsofim.2020.007.02.11, 2020.

3. ARSAD S., DARYANTO A.O., SARI L.A., SAPUTRA D.K., PRATIWI F.D. Community-Based Ecotourism and Its impact on the social and economic conditions: A case study in Blekok, Situbondo Regency, Indonesia. Journal of Environmental Management and Tourism, 3 (51), 797, DOI:10.14505/jemt.v12.3(51).19, 2021.

4. BARR J.G., ENGEL V., FUENTES J.D., ZIEMAN J.C., O'HALLORAN T.L., SMITH III T.J., ANDERSON G.H. Controls on mangrove forest-atmosphere carbon dioxide exchanges in western Everglades National Park. Journal of Geophysical Research, 115 (Go2020), 1, 2010.

5. MUSA M., MAHMUDI M., ARSAD S., BUWONO N.R. Feasibility study and potential of pond as silvofishery in coastal area: Local case study in Situbondo Indonesia. Regional Studies in Marine Science, 33 (100971), 1, 2020.

6. MAHMUDI M., ADZIM A., FITRI D.H., LUSIANA E.D., BUWONO N.R., ARSAD S., MUSA M. Performance of Avicennia alba and Rhizopohora mucronata as lead bioaccumulator in Bee Jay Bakau Resort, Indonesia. Journal of Ecological Engineering, 22 (2), 169, https:/doi. org/10.12911/22998993/131032, 2021.

7. MUSA W.J.A., BIALANGI N., SITUMEANG B., SILABAN S. Triterpenoid compound from metanol extract of mangrove leaves (Sonneratia alba) and anticholesterol activity test. Jurnal Pendidikan Kimia, 11 (1), 18, 2019.

8. ISWANDAR M., DEWIYANTI I., KURNIANDA V. Alleged carbon sequestration in mangrove vegetation in the mangrove area of Gampong Iboih, District Sukakarya, Sabang City. Jurnal Ilmiah Mahasiswa Kelautan dan Perikanan Unsyiah, 2 (4), 512, 2017.

9. Standar Nasional Indonesia. Measurement and calculation carbon stocks - Field measurements for assessment forest carbon stocks (ground-based forest carbon accounting). SNI 7724, Badan Standardisasi Nasional, 2011.

10. RAHIM S., BADERAN D.K., HAMIDUN M.S. Species diversity, biomass and carbon stock in Torosiaje mangrove forest, Pohuwato Regency, Gorontalo Province. Jurnal Pro-Life, 5 (3), 650, 2018.

11. Standar Nasional Indonesia. How to test nitrate levels with a spectrophotometer, 2011.

12. Standar Nasional Indonesia. How to test phosphate levels with a spectrophotometer. SNI 6989. 31-2005, 2005.

13. PATEL N.M., SHIYAN R.L. Coefficient of variation in field experiments and yardstick thereof - an empirical study. Current Science, 81 (9), 385, 2001.

14. MANDARI D.Z., GUNAWAN H., ISDA M.N. Assessment of biomass and carbon stored in the mangrove forest ecosystem in the Bandar Bakau Dumai area. Jurnal Riau Biologia, 1 (3), 17, 2016.

15. BROWN S. Estimating Biomassa dan Biomassa Change for Tropical Foresta Primer. FAO Forestry Paper 134. Rome, 1997. 
16. AMIRA S. Estimation of biomass of Rhizophora apiculata bi. in the Batu Ampar mangrove forest, Kubu Raya Regency, West Kalimantan. Skripsi, Institut Pertanian Bogor, Bogor, 2008.

17. LEMBANG R.K., HULISELAN S., ADJI F. Estimation of biomass and carbon stored in mangroves Rhizophora apiculata and Sonneratia alba in Simau Village. Jurnal Hutan Pulau- Pulau Kecil, 3 (1), 68, 2019.

18. TUMANGGER B.S., FITRIAN I. Identification and characteristics of mangrove root types based on soil conditions and seawater salinity in Kuala Langsa. Jurnal Biologica Samudra, 1 (1), 009, 2019.

19. PRAKOSO T.B., AFIATI N., SUPRAPTO D. Biomass carbon content and $\mathrm{CO}_{2}$ uptake in mangrove stands in the Bedono mangrove conservation area, Demak. Journal of Maqueres, 6 (2), 156, 2017.

20. HIKMATYAR M.F., ISHAK T.M., PAMUNGKAS A.P., SOFFIE S., RIJALUDIN A. Estimated carbon stored in tree stands in the coastal forest of Kotok Besar Island, Western Part, Seribu Islands. Jurnal Biologi, 8 (1), 40, 2015.

21. AKBAR C., ARSEPTA Y., DEWIYANTI I., BAHRI $S$. Alleged carbon uptake in mangrove vegetation, in the mangrove area of Beureunut Village, Seulimum District, Aceh Besar District. Jurnal Laot Ilmu Kelautan, 1 (2), 63, 2019.

22. ZURAIDAH S. Physical aspects of mangrove soil Rhizophora sp. in the mangrove area of Aceh Jaya Regency. Journal of Aceh Aquatic Science, 1 (2), 101, 2018.

23. FARHABY A.M. Preliminary study of the health condition of mangrove forests in Kurau Timur Village, Central Bangka Regency, Bangka Belitung Islands Province. Jurnal Biosains, 5 (3), 99, 2019.

24. USDA Natural Resources Conservation Service. Soil quality indicators: $\mathrm{pH}, \mathbf{1 9 9 8}$.

25. SA'DIYAH H., AFIATI N., PURNOMO P.W. Sediment organic matter content and water $\mathrm{H} 2 \mathrm{~S}$ levels inside and outside the mangrove stands Bendono Village, Demak Regency. Journal of Maqueres, 7 (1), 78, 2018.

26. UTOJO A., MUSTAFA HASNAW I. Model of Suitability of Locations for Aquaculture Development in the Coastal Area of Pontianak Regency, West Kalimantan. Jurnal Ristek Akukultur, 5 (3), 465, 2010.

27. RAKMAWATI, HARIYANTO, S. Ecological study of primitive brachiopods lingula sp. in probolinggo, east java, indonesia. Ecology, Environment and Conservation, 26, S54, 2020.
28. HARTOKO A., SOEDARSONO P., INDRAWATI A. Analysis of chlorophyll- $\alpha$, nitrate and phosphate in mangrove vegetation based on field data and geoeye satellite data on Parang Island, Karimunjawa Islands. Journal of Management of Aquatic Resources, 2 (2), 28, 2013.

29. ARIZUNA M., SUPRAPTO D., MUSKANANFOLA M.R. 29. The content of nitrate and phosphate in the pore water of sediments in the river and estuary of the Wedung Demak river. Diponegoro Journal of Maquares, 3 (1), 7, 2014

30. AL DIANA N.Z., SARI L.A., ARSAD S., PURSETYO K.T., CAHYOKO Y. Monitoring of Phytoplankton Abundance and Chlorophyll-a Content in the Estuary of Banjar Kemuning River, Sidoarjo Regency, East Java. Journal of Ecological Engineering, 22 (1), 29, 2021.

31. SARI L.A., SARI P.D.W., NINDARWI D.D., ARSAD S., AFFANDI M. Harmful algae identification in Bomo water environment, Banyuwangi, East Java, Indonesia. Ecology, Environment and Conservation 25 (July Suppl. Issue): S26, 2019.

32. NINDARWI D.D., SARI L.A., WULANSARI P.D., SAMARA S.H., SANTANUMURTI M.B.. Use of hydrogen peroxide to improve potential redox land preparation of land towards increasing production of traditional shrimp vanname (Litopeaneus vanname) in Wringin Putih, Muncar, Banyuwangi. In IOP Conference Series: Earth and Environmental Science 441 (1), 2020.

33. MELATI V.H., SARI L.A., CAHYOKO Y., ARSAD S., PURSETYO K.T., DEWI N.N., IDRIS M.H.. Gastropod Community Structure as Environmental Change Signals for Tropical Status In Sedati Waters, Indonesia. Ecological Engineering Environmental Technology, 22 (3), 82, 2021.

34. HUTAMI W.W., SARI L.A., MASITHAH E.D., SAHIDU A.M., PURSETYO K.T. Effect of Water Quality on Community Structure of Bivalve at Segoro Tambak Estuary, Sidoarjo, East Java, Indonesia. Asian Journal of Water, Environment and Pollution, 17 (3), 81, 2020.

35. BUDIASIH R., SUPRIHARYONO, MUSKANANFOLA M.R. Analysis of the content of organic matter, nitrate, phosphate in sediments in the mangrove area of Rhizopora and Avicennia species in Timbusloko Village, Demak. Diponegoro. Journal of Maquares, 4 (3), 66, 2015.

36. DEWI N.N.D.K., DIRGAYUSA G.N.P., SUTEJA Y. The nitrate and phosphate content of sediments and their relationship to mangrove density in the Mertasari area in the Suwung TPA river flow, Denpasar, Bali. Journal of Marine and Aquatic Science, 3 (2), 180, 2017. 